\title{
MAKNA QIRAAH DAN TILAWAH DALAM ALQURAN PERSPEKTIF TEORI ANTI SINONIMITAS MUHAMMAD SYAHRUR
}

\author{
Sandi Wahid Rahmat Nugraha ${ }^{1}$, Irwan Abdurrohman ${ }^{2}$ \\ 1 Fakultas Ushuluddin UIN Sunan Gunung Djati Bandung, Jl. AH. Nasution No. 105 Bandung, Jawa Barat, \\ Indonesia; Email: sandiwahidr@gmail.com \\ 2 Fakultas Ushuluddin UIN Sunan Gunung Djati Bandung, Jl. AH. Nasution No. 105 Bandung; Email; \\ irwanabdurrohman@uinsgd.ac.id \\ * Correspondence
}

Received: 2020-07-01 ; Accepted: 2020-07-12; Published: 2020-07-13

\begin{abstract}
Commonly, synonymity of the meaning of a word exists in any language. In general opinion, the Quran also contains this synonymity, because - although it is a transcendent revelation of God - the Quran has come into being in the form of Arabic texts. The question is, is it true that the Quran recognizes this synonymity? Muhammad Syahrur, with his anti-synonymity theory, believes that every word in the Quran is unique so that no two or more words are synonymous. This study wants to prove the idea of Syahrur's anti-synonymity by taking the case of words that have been considered synonyms, namely the terms qiraah and tilawah. The purpose of this research is to understand the background of Syahrur's anti-synonymity theory and to find contrasting and significant differences between the two words that are mostly considered synonyms. Syahrur assumes that accepting synonymity is the same as rejecting the historicity of language. Especially so in the case of the Quran as a miraculous book. This research uses semantic analysis, which is then correlated with the perspective of Syahrur's anti-synonymity theory. This research finally confirmed Syahrur's anti-synonymity theory. After conducting a semantic review, it turns out that the two words have quite significant differences in meaning. In the perspective of Syahrur, qiraah in the present context is to analyze, study, or examine a matter, while tilawah is a scientific seminar
\end{abstract}

Keywords: qiraah; tilawah; sinonimitas; Syahrur.

\begin{abstract}
Abstrak: Sinonimitas makna sebuah kata dalam bahasa manapun merupakan hal yang lazim terjadi. Menurut pandangan umum, Alquran pun tidak terlepas dari unsur sinonimitas ini, sebab - meski ia wahyu Tuhan yang bersifat transenden - Alquran telah mewujud dalam bentuk teks berbahasa Arab. Namun, benarkah Alquran mengakui adanya sinonimitas? Muhammad Syahrur dengan teori anti-sinonimitasnya meyakini bahwa setiap kata dalam Alquran bersifat unik, sehingga tidak ada dua kosakata atau lebih yang sinonim. Penelitian ini ingin membuktikan gagasan anti-sinonimitas Syahrur tersebut dengan mengambil kasus pada kosakata yang selama ini dianggap sinonim, yaitu kata qiraah dan tilawah. Tujuan penelitian ini adalah memahami hal-hal yang menyebabkan munculnya teori anti sinonimitas Syahrur, dan menemukan perbedaan yang kontras dan signifikan antara kedua kata yang dianggap sinonim tersebut. Karena, Syahrur berteori bahwa menerima sinonimitas sama dengan menolak historisitas bahasa, apalagi pada kasus Alquran yang penuh mukjizat. Metode penelitian ini menggunakan pisau analisis semantik yang kemudian dikorelasikan dengan perspektif teori anti-sinonimitas Syahrur. Penelitian ini pada akhirnya membenarkan teori anti-sinonimitas Syahrur. Setelah dilakukan telaah secara semantik, ternyata kedua kata itu memiliki perbedaan makna yang cukup signifikan. Dalam perspektif Syahrur, qiraah dalam konteks sekarang adalah tindakan menelaah, mengkaji atau melakukan penelitian terhadap suatu hal; sedangkan tilawah adalah seminar ilmiah.
\end{abstract}

Kata Kunci: qiraah; tilawah; sinonimitas; Syahrur. 


\section{Pendahuluan}

Tidak dapat disangsikan, Alquran diturunkan oleh Allah swt. sebagai petunjuk dan untuk mengarakan manusia ke jalan yang paling lurus. Maka dari itu, perlu dilakukan penemuan maknamakna dari firman Allah tersebut. Urgensi Alquran sebagai manual book umat Muslim untuk mencapai cita-cita Alquran yang difirmankan oleh Allah Swt. tersebut tidak bisa ditawar lagi. Sehingga, jalan yang ditempuhnya pun yaitu penemuan makna-makna dalam Alquran-juga merupakan hal yang mendesak adanya. Karena mendesaknya dalam penyingkapan dan penemuan makna-makna sebagai pemosisian Alquran sebagai manual book umat muslim tersebut, Arkoun mengatakan bahwa Alquran merupakan teks yang terbuka atas segala makna dan teks bagi seluruh umat manusia(Harb 2003).

Salah satu pendekatan dalam upaya penggalian dan pengungkapan makna dalam Alquran adalah pendekatan semantik( Khan et all., 2019., hal. 570). Pendekatan ini adalah sebuah pendekatan studi Alquran yang menjadikan lafal Alquran sebagai objek( Khan et all., n.d., 570), terutama pada kata-kata kunci (key word) yang terdapat dalam redaksi ayat. Key word ini memiliki peranan penting untuk menangkap makna yang terdapat dalam redaksi ayat(Saepudin et., all 2016., hal.10-11). Bagaimana Tuhan mendistribusikan kata-katanya dalam redaksi ayat, menjadi hal yang menari dalam kajian semantik(Ismail 2016b, 139-40). Terkait dengan pendekatan bahasa dalam Alquran, menarik apa yang diungkapkan Izutsu, "Allah mewahyukan melalui bahasa, dan bukan dalam bahasa yang misterius melainkan bahasa manusia yang jelas dan dapat dimengerti"(Izutsu 2003). Itulah sebabnya manusia dapat mempelajari Alquran dari berbagai aspek, termasuk bahasa atau linguistiknya.

Menyinggung tentang diskursus kebahasaan, salah satu tema yang menjadi perdebatan sehingga terjadi dikotomi di dalamnya adalah mengenai sinonimitas dalam Alquran. Sinonim ialah ragam lafaz, namun mempunyai satu makna yang sama (Shihab 2015a). Seperti kata khāfa-yakhāfu dengan khasyiya-yakhsya yang sama-sama diartikan takut(Yunus 1972, 122). Atau dalam bahasa Indonesia, cerdas-cerdik, mayat-bangkai-jenazah, matahari-surya dan lain-lain. Menurut Quraish Shihab, keunikan bahasa Arab terlihat juga pada kekayaannya, bukan saja pada kelamin kata, atau pada bilangannya, yaitu tunggal (mufrad), dual (musannā), dan plural (jama'), tetapi juga pada kekayaan kosakata dan sinonimnya(Shihab 2015b, 30). Setidaknya ada dua pandangan ulama yang berpendapat ada tidaknya sinonimitas dalam Alquran. Pertama, kelompok ulama yang menolak sinonimitas dalam Alquran, alias berteori bahwa bahasa Alquran itu anti sinonimitas. Mereka berhujah bahwa setiap kalimat dalam bahasa Arab (Alquran) memiliki makna yang spesifik, yang membedakan antara satu kalimat dengan lainnya. Kedua, ulama yang sependapat dengan adanya sinonimitas dalam Alquran. Mereka berpendapat bahwa sinonimitas boleh terjadi dalam bahasa, seperti dua istilah yang memiliki kesamaan arti atau sebagai sifat dari kalimat tersebut(Riyanto 2014, 147-48).

Menarik untuk menanggapi dikotomi pendapat yang terjadi mengenai sinonimitas tersebut melalui ungkapan Khalid bin Usman as-Sabt. Beliau menguraikan bahwa sinonim (al-tarāaduf) adalah ragam lafaz yang mempunyai makna yang sama. Memang tidak terdapat perbedaan dengan definisi sinonim yang telah penulis paparkan sebelum ini, tapi beliau menambahkan yang dimaksud makna yang dianggap sama adalah makna asli atau makna umum atau makna tampak, bukan makna lafaz yang sempurna. Karena setiap lafaz pasti mempunyai makna khusus(Al-Sabt n.d., 459; Rofiq Nurhadi 2017). Oleh sebab itu, sebagian kalangan mengakui keberadaan sinonim dan sebagian yang lain mengingkarinya(Al-Sabt 1421). Golongan yang mengingkari sinonimitas mengakui bahwa sinonimitas dalam bahasa merupakan hal yang lumrah adanya karena merupakan bagian dari fenomena bahasa. Dalam ranah mu'jam misalnya, pinjam-meminjam kata merupakan hal perlu untuk memperjelas maksud yang dituju. Golongan yang mengonfirmasi adanya sinonimitas pun tidak bisa membantah penggunaan kata syāri' dalam hal penamaan jalan dan bukan tharìq. juga terjadi ketidakcocokan apabila menggantinya dengan thariāq. Sehingga pada dasarnya golongan yang 
anti terhadap sinonimitas, pada saat yang bersamaan juga mengamini sinonimitas. Begitu pun golongan yang mengamini sinonimitas, pada saat yang sama juga mengingkari sinonimitas.

Maka perbedaan pendapat mengenai sinonimitas adalah tentang perbedaan titik pijak melihat. Penganut sinonimitas melihatnya secara fungsional dalam berbahasa. Sedangkan pengingkar sinonimitas tidak bisa mengabaikan makna khusus dari dua kata yang dianggap sinonim. Kekhawatiran pengingkar sinonimitas adalah terjadinya perlakuan pukul rata semua kata yang dianggap sinonim dengan makna yang seragam. Sehingga secara tidak sadar telah mereduksi makna dan menutup diri dari eksplorasi makna khusus yang terkandung di dalamnya. Apalagi kalau hal tersebut diaplikasikan dalam pemaknaan Alquran, tentu ini akan kontradiktif dengan ayat rabbanā mā khalaqta hādza $\bar{a}$ ăthilā. Maka tidak mungkin Allah menempatkan makna yang sama di dalam lafaz yang berbeda karena itu merupakan ketidakbermanfaatan.

Kosakata dalam Alquran yang dianggap sinonim, salah satunya kata qiraah dan tilawah di mana keduanya bila diterjemahkan ke dalam bahasa Indonesia diartikan membaca. Masing-masing ayat yang mengandung kata qiraah dan tilawah misalnya, Al-Nahl[16]:98:

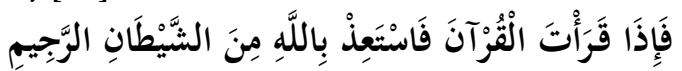

Maka apabila engkau (Muhammad) hendak membaca Al-Qur'an, mohonlah perlindungan kepada Allah dari setan yang terkutuk.

Dan al-Naml[27]:92:

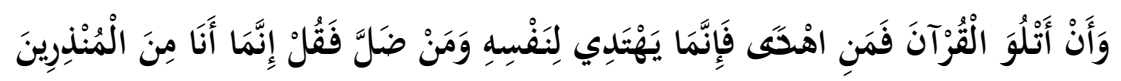

Dan agar aku membacakan Al-Qur'an (kepada manusia). Maka barangsiapa mendapat petunjuk maka sesungguhnya dia mendapat petunjuk untuk (kebaikan) dirinya, dan barangsiapa sesat, maka katakanlah, "Sesungguhnya aku (ini) tidak lain hanyalah salah seorang pemberi peringatan."

Apakah Allah membedakan ragam lafadz dengan arti harfiah membaca di atas dengan tanpa alasan? Maka dari itu, pemaknaan kata qiraah dan tilawah yang hanya terbatas pada arti bacamembaca kurang memuaskan karena terandaikan wilayah makna khusus yang belum tereksplorasi. Pemaknaan yang seperti itu tidak mendapatkan konsep yang utuh dan komprehensif dalam dunia akademis.

Bagaimana dengan Syahrur? Apabila mengacu pada dikotomi mengenai sinonimitas dalam Alquran, maka Syahrur tergolong pada sisi yang tidak setuju dengan adanya sinonimitas dalam Alquran, dengan kata lain berpandangan anti sinonimitas. Ini terlihat dari redefinisi yang dilakukan oleh beliau terhadap kata dalam Alquran yang dianggap sinonim seperti al-kitāb, al-qur'ān, al-furqān dan sebagainya. Syahrur mengingkari teori sinonimitas dalam Alquran dengan alasan menerima sinonimitas sama dengan menolak historisitas perkembangan bahasa. Padahal faktanya bahasa itu mengalami perkembangan diakronis (Al-Sabt 1421). Meskipun tidak dapat disangkal bahwa pengingkaran terhadap sinonimitas bukanlah sesuatu hal yang baru, namun aplikasi dari pengingkaran sinonimitas yang dilakukan oleh Syahrur tersebut bisa dikatakan unik. Implikasi dari hal tersebut, beliau sampai pada tahap mengkritisi dan melakukan redefinisi terhadap kata-kata dalam Alquran yang dianggap sinonim sehingga melahirkan eksplorasi makna yang baru dan segar.

Metode penelitian ini menggunakan menggunakan metode analisis semantik sebagai pisau analisis demi terjaminnya ketajaman hasil eksplorasi makna kedua kata tersebut sehingga dapat muncul perbedaan yang kontras dan signifikan. Kemudian mengkorelasikannya dengan pendekatan anti-sinonimitas Muhammad Syahrur. Tujuan penelitian ini adalah memahami hal-hal yang menyebabkan munculnya teori anti sinonimitas Syahrur, dan menemukan perbedaan yang kontras dan signifikan antara kedua kata yang dianggap sinonim tersebut. Dalam penelitian ini, penulis melakukan pemaparan latar belakang pemikiran Syahrur mengenai gagasan anti sinonimitas, kemudian mengambil sampel dua kosakata dalam Alquran yang dianggap sinonim yakni kata qirāah 
dan tilāwah untuk dianalisis menggunakan metode semantik. Kemudian hasilnya dikorelasikan dengan perspektif Syahrur.

\section{Muhammad Syahrur dan Teori Anti Sinonimitas}

\section{Riwayat Hidup}

Muhammad Syahrur adalah seorang insinyur yang dilahirkan di Damaskus, Syria pada tanggal 11 April 1938. Dia mengawali karir intelektualnya pada pendidikan dasar dan menengah di tanah kelahirannya, tepatnya di lembaga pendidikan Abdurrahman al-Kawakibi, Damaskus. Pendidikan menengahnya dirampungkan pada tahun 1957, dan segera setelah menuntaskan pendidikan menengahnya, Syahrur melanjutkan studinya ke Moskow, Uni Soviet (sekarang Rusia) untuk mempelajari teknik sipil (handasah madaniyah) atas beasiswa pemerintah setempat(Yusuf, 2014, 55). Di negara inilah, Syahrur mulai berkenalan dan kemudian mengagumi pemikiran Marxisme, sungguh pun ia tidak mendakwa sebagai penganut aliran tersebut. Gelar diploma dalam bidang teknik sipil tersebut, ia raih pada tahun 1964.

Setelah meraih gelar diploma, pada tahun 1964, Syahrur kembali ke Syria untuk mengabdikan dirinya sebagai dosen pada Fakultas Teknik di Universitas Damaskus. Pada tahun itu pula, Syahrur kembali melanjutkan studi ke Irlandia, tepatnya di University College, Dublin dalam bidang yang sama. Pada tahun 1967, Syahrur berhak untuk melanjutkan penelitian pada Imperial College, London. Pada bulan Juni tahun itu, terjadilah perang antara Inggris dan Syria yang mengakibatkan renggangnya hubungan diplomatik antara dua negara tersebut, namun hal tersebut tidak menghambatnya untuk segera menyelesaikan studinya. Terbukti ia segera berangkat kembali ke Dublin untuk menyelesaikan program master dan doktoralnya di bidang mekanika pertanahan (soil mechanics) dan teknik bangunan (foundation engineering). Gelar doktornya diperoleh pada tahun 1972. Selanjutnya Syahrur secara resmi menjadi staf pengajar di Universitas Damaskus hingga sekarang(Hidayat, 2017, 207). Di samping posisinya sebagai dosen, sebenarnya Syahrur juga menjadi konsultan teknik. Pada tahun 1982-1983, ia dikirim pihak universitas untuk menjadi staf ahli pada alSaud Consult, Saudi Arabia. Selain itu, bersama beberapa rekannya di Fakultas, Syahrur membuka Biro Konsultasi Teknik di Damaskus(Syahrur, 2015, 5).

Syahrur yang dikenal sekarang ini tidak bisa lepas dari sejarah masa kecilnya yang dibesarkan dalam lingkungan keluarga yang berpikir kritis dalam beragama. Sikap keberagamaan ayah Syahrur bisa dibilang unik. Walaupun secara penampilan berwajah agamis, namun ia memiliki pola pikir modern dan pola pikir keagamaan yang sadar akan realitas kehidupan yang dihadapi. Pola pikir ayahnya ini banyak membentuk Syahrur, baik dalam karakter akademis maupun sosial. Sebagaimana diakui oleh Syahrur, suatu hari ayahnya mengajarkan bahwa beribadah pada Tuhan sama pentingnya dengan kejujuran, kerja dan mengikuti hukum alam. Selain itu, Syahrur juga selalu ingat dengan ilustrasi yang diberikan oleh ayahnya mengenai agama, "Jika kamu ingin menghangatkan tubuh, jangan membaca Alquran, tapi nyalakan api di tungku"(Malik, 2017, 120). Dari segi pendidikan formal, Syahrur memang tidak concern terhadap kajian keislaman (islamic studies). Ia lebih concern dalam bidang teknik, hingga meraih jenjang doktor di bidang yang sama, Mekanika Pertanahan dan Fondasi(Mubarok, 2007, 139). Sejarah intelektual Syahrur memang secara formal beralurkan sains. Karena itu, beberapa kritikus melemparkan argumen, seharusnya Syahrur lebih tepat dipandang sebagai ahli ilmu eksak dibandingkan sebagai pemikir atau cendekiawan Muslim. Meski disiplin utama keilmuannya pada bidang teknik, namun itu tidak menghalanginya untuk mendalami disiplin ilmu yang lain semisal filsafat, yang selanjutnya menjadi perspektif Syahrur dalam kajian keislaman terutama tafsir. Ini terjadi, terutama setelah pertemuannya dengan Ja'far Dek al-Bab, rekan satu almamater di Syria dan teman seprofesi di Universitas Damaskus. Kontaknya itu, telah memberi arti yang cukup berarti dalam pemikirannya, yang kemudian tertuang dalam karya monumentalnya, yaitu al-Kitāb wa Al-Qur'ān: Qirā'ah Mu'āsirirah(Syahrur, n.d. hal.46). 


\section{Gagasan Anti Sinonimitas Syahrur}

Kajian Syahrur terhadap Alquran (dalam bukunya al-Kitab) membuat banyak kalangan terusik akibat pendapatnya yang anti mainstream. Dalam bukunya tersebut, Syahrur telah sampai pada kesimpulan yang sama sekali baru dan berbeda dari mainstream pemahaman saat ini(Syahrur, n.d.hal.19). Tentu hal ini menimbulkan tanda tanya, bagaimana beliau bisa sampai pada kesimpulan tersebut? Sebagaimana dipaparkan oleh Ja'far Dek al-Bab dalam pengantar buku al-Kitab, Syahrur percaya bahwa Alquran adalah mukjizat abadi bagi Muhammad saw. sebagai penutup para nabi dan rasul(Syahrur, n.d. hal.19). Maka dari itu beliau meyakini tanpa ragu bahwa Al-Qur'än șalih likulli zamān wa makān. Lebih lanjut ia menyatakan bahwa Alquran merupakan kitab berbahasa Arab otentik yang memiliki dua sisi kemukjizatan, sastrawi (al-i'jāz al-baläghi) dan ilmiah (al-i'jāz al-'ilmi). Untuk memahami aspek sastrawi Alquran perlu digunakan pendekatan deskriptif-fungsional (al-manhaj alwașfi al-wazifi), sedangkan aspek ilmiahnya harus dipahami dengan pendekatan historis-ilmiah (almanhäj al-tärikhi al-'ilmi), yang keduanya diletakkan dalam bingkai studi linguistik. Pendekatan pertama dilakukan dengan cara memadukan analisis sastra (balagah) dengan analisis gramatika (nahwu). Selama ini, kedua disiplin linguistik tersebut lebih sering dikaji secara terpisah, sehingga menghilangkan potensi keduanya sebagai alat bantu untuk menganalisis teks-teks keagamaan secara kritis. Sedangkan pendekatan kedua, menuntut penolakan terhadap fenomena sinonimitas dalam bahasa dan menuntut studi yang mendalam terhadap setiap terma yang selama ini dianggap sinonim(Syahrur, n.d.hal.819). Pertanyaan berikutnya adalah metode apa yang dipakai oleh beliau dalam melakukan kajiannya tersebut?

Awalnya metode historis-linguistik diperkenalkan oleh Ja'far Dek al-Bab lewat penelitiannya, yaitu al-Khaṣais al-Binwiyah li al-'Arabiyah fi Dạu'i al-Dirāsāt al-Lisāniyah al-Hạiș̣ah yang mana beliau ciptakan asasnya berdasarkan perspektif Abu Ali al-Farisi yang berasal dari dua teori yang saling melengkapi, yaitu teorinya Ibnu Jinni dan al-Jurjani(Syahrur, n.d.hal.20). Ibnu Jinni dalam penelitiannya (al-Khașaiṣ) menemukan bahwa terdapat hubungan logis antara suara dengan makna yang dihasilkan. Ia menjelaskan bahwa bahasa manusia pada mulanya merupakan suara-suara yang diucapkan manusia secara sadar sebagai media menyampaikan maksud tertentu (baik ide maupun gagasan) kepada orang lain dalam kehidupan bermasyarakat. Beliau sampai pada kesimpulan, bahasa tidak tercipta pada waktu yang sama tapi pada waktu yang berlainandan bahasa terus menerus terjaga dalam bentuknya yang konsisten(Syahrur, n.d. hal.20-21) Sedangkan al-Jurjani dalam Daläil al-I'jaz fi Ilmi al-Ma'añi,membahas hubungan antara bahasa dengan pikiran. Ia memaparkan, sebelum melakukan pengungkapan bahasa, manusia lebih dulu membayangkannya dalam pikiran mengenai maksud atau konsep yang ingin disampaikannya. Sehingga, beliau menyimpulkan, suatu kata tidak mungkin mengandung makna yang ada pada kata lain.(Syahrur, n.d. hal.21)

Kedua teori di atas saling melengkapi satu sama lain. Selanjutnya ini mengerucut di dalam teorinya Abu Ali al-Farisi, yaitu berasumsi bahwa; 1) Bahasa adalah sebuah sistem, 2) Bahasa adalah hasil kesepakatan dan hubungan struktur \& fungsi bahasa yang berkaitan dengan praktik bahasa, 3) Keterkaitan bahasa dengan pikiran. Konsekuensi diamininya asumsi-asumsi di atas adalah bahasa tidak mengenal sinonimitas. Begitu juga Alquran yang telah hadir dalam tekstual bahasa, maka dalil tersebut perlu diterapkan. Dan itulah yang dilakukan oleh Syahrur. Beliau menjadikan hal tersebut sebagai landasan teori dalam rangka penafsiran ulang terhadap tema-tema yang terdapat dalam Alquran sesuai dengan konteks ruang dan waktu abad kedua puluh. Dalam bukunya, titik tolak penelitiannya adalah terma-terma yang selama ini dipahami dan diyakini sebagai sinonim, yaitu alkitab, al-qur'ān, al-furqān dan seterusnya. Di sini beliau melakukan dekonstruksi dan redefinisi terhadap terma-terma tersebut yang pada akhirnya beliau melahirkan konsep baru, di mana konsep ini nantinya akan menjadi kunci bagi para intelektual untuk meneliti dan memahami pemikirannya. Terlihat bahwa metode historis-ilmiah yang digunakan dalam penelitiannya bukanlah karya orisinil miliknya. Peran Syahrur "hanya" mengadopsi metode yang diperkenalkan Ja'far Dek al-Bab kepadanya. Meskipun tentu saja terdapat faktor tertentu yang membuat akhirnya Syahrur sepakat 
dengan metode tersebut. Yaitu latar pendidikan dalam bidang sains yang dimiliki Syahrur ternyata memiliki pengaruh kuat, yang membuatnya senantiasa mengedepankan sifat-sifat empiris, rasional dan ilmiah. Yang menjadi ciri khas dari Syahrur adalah pengaplikasian asumsi tersebut (yaitu anti sinonimitas) terhadap kajian Alquran dengan mengungkap detilitas makna dan titik berangkatnya yang merupakan seorang expert keilmuan sains yang berkarakter ilmiah kontemporer sehingga melahirkan argumentasi baru terkait konsep dalam diskursus Alquran. Pada akhirnya hal tersebut menjadi hal yang paling tipikal dari Syahrur.

Fakta adanya perdebatan ulama linguistik tentang eksistensi sinonim, nampaknya tidak membuatnya bergeming. Syahrur tetap bersikukuh dengan penolakannya terhadap sinonimitas dan terus mengembangkan teorinya dalam melakukan pembacaan kontemporer terhadap Alquran. Hal ini dapat dilihat dalam buku-buku yang dikarangnya belakangan. Terkait hal ini ia mengatakan, "Jika kita memandang sebuah buku tentangkedokteran atau teknik yang ditulis dalam bahasa apapun, maka kita tidak akan menemukan fenomena sinominitas di dalamnya. Jika sebuah sel berbeda dari sel lain, maka penulis buku akan memberikan nama lain terhadap sel tersebut, meskipun perbedaannya sangat kecil. Demikian juga ketika sebuah batasan yang belum diketahui dalam matematika berbeda dengan batasan lain,maka penyusun buku itu akan memberikan simbolsimbolyang berbeda (S1, S2, S3,...). Demikian juga dalam rangka ketelitian ilmiah. Mengapa hal ini (tidak adanya sinominitas dalam bidang ilmu pengetahuan demi ketelitian ilmiah) yang notabene berasal dari manusia, kita terima dan kita akui dengan ketelitian ilmiah, sementara di sisi lain kita bersikeras mengatakan bahwa simbol-simbol(terminologi-terminologi) dalam Kitabullah adalah sama (sinonim). Bagaimana mungkin makhlukTuhan dalam hal pengungkapan bisa lebih teliti dari pada Tuhannya dalam hal pewahyuan?"(Syahrur, 1994, 37).

Perspektif empiris, rasional dan ilmiah yang digunakan dalam memberikan argumentasi mengenai sinonimitas tersebut merupakan konsekuensi logis dari dialektika beliau dengan keilmuan sains modern yang memang merupakan ekspertasi seorang Syahrur.

\section{Semantik Alquran}

Pendekatan bahasa adalah sebuah pendekatan studi Alquran yang menjadikan lafal-lafal Alquran sebagai obyek. Pendekatan inimenekankan analisisnya pada sisi kebahasaan dalam memahami Alquran. Secara praktis, pendekatan ini dilakukan dengan memberikan perhatian padaketelitian redaksi dan bingkai teks ayat-ayat Alquran(Zenrif, 2008, 51). Dalam kasus semantik Al-Qu'an, maka yang terjadi adalah menjadikan tanda-tanda dan lambang-lambang bahasa dalam Alquran sebagai objek kajian ilmu semantik, untuk kepentingan meraih makna dibaliknya. Dalam pengamatan Izutsu, setiap kata sudah tentu memiliki makna dasardan makna relasional. Makna dasar dapat disinonimkan dengan makna leksikal, sementara makna relasional hampir mendekati makna kontekstual(Zulfikar 2018, 112). Ketika suatu kata digunakan dalam kalimat atau konsep tertentu, maka ia memilikimakna baru yang diperoleh(Zulfikar 2018, 112), dari posisi dan hubungannya dengan kata-kata laindalam struktur kalimat tersebut.

\section{Analisis Kata Qiraah dan Tilawah dalam Alquran menurut Syahrur}

\section{Sebaran Kata Qiraah dan Tilawah dalam Alquran}

Kata qiraah dalam Alquran terdapat 14 derivasi dan jumlah total penyebutannya sebanyak 89 kali. Karena kepentingan penelitian ini adalah untuk mengungkap makna membaca pada kata qiraah, maka tiga derivasi dari kata qiraah yaitu al-Qur'an,qur'annan, dan quru'in tidak masuk dalam wilayah penelitian karena berbeda tema bahasan(Baqi, n.d., 685-686). Sedangkan kata tilawah dalam Alquran terdapat 20 derivasi dan jumlah total penyebutannya sebanyak 61 kali. 


\section{Analisis Diakronik Term Qiraah dan Tilawah}

Analisis diakronik adalah sebuah analisa untuk mengetahui pandangan sebuah masyarakat terhadap suatu bahasa(T.Izutsu 1997, 23). Pada prinsipnya analisis diakronik menitikberatkan pada unsur waktu. Maka dengan analisis diakronik dapat diketahui pertumbuhan dan perubahan setiap kata pada jenjang waktu tertentu(Izutsu, 2003, 23). Untuk kepentingan tersebut maka kosakata perlu dilihat dalam tiga fase: a.) Masa sebelum turunnya Alquran (Pre-Qur'anic meaning), b.) Masa proses penurunan Alquran (Qur'anic age meaning), c.) Masa pasca Alquran (Post Qur'anic meaning).

Kecenderungan makna kata qiraah pada masa sebelum Alquran turun digunakan dalam konteks keterhimpunan atau keberkumpulan bendawi yang umum. Misalnya dalam mengungkapkan belum adanya janin di dalam rahim. Pada masa Alquran turun terjadi upaya transendentalisasi(Ismail, 2016, 142), (pe-naik kelas-an) kata qiraah. Maknanya menjadi ungkapan yang berkaitan dengan aspek kognitif manusia. Makna yang muncul pada masa ini yaitu pelafalan (melakukan penghimpunan rangkaian kata sehingga dapat diindra), penyampaian, proses kognisi, menganalisa, mempelajari, menginsafi, melakukan refleksi, menelaah, pengujaran, membaca hafalan dan membuat ingat. Dari makna-makna tersebut tidak ada satu pun yang merujuk pada wujud bendawi kecuali kata Alquran yang artinya himpunan, karena terdiri dari himpunan surah-surah. Pada masa setelah Alquran, kosakata baru muncul seiring perkembangan zaman yang berasal dari bentukan kata ini. Yaitu Taqarra'a artinya mempelajari fiqih, al-miqra' artinya tempat meletakkan kitab, istaqra'a artinya meneliti, al-istiqra' artinya penelitian, al-țariqatu al-istigra'iyyah artinya metode deduktif, iqtara (dengan huruf ya lazimah di akhri) artinya menyelidiki. Meskipun dalam hal keberagaman kosakata menunjukkan perluasan, semua kosakata tersebut masih sama-sama berkaitan dengan aspek kognitif manusia dan tetap spirit makna yang dikehendaki Alquran.

Sedangkan kata tilawah, Kecenderungan makna kata tilawah pada masa sebelum Alquran turun digunakan dalam konteks pengiringan atau tindakan mengikuti (baik badani atau meneladani) bendawi atau kemakhlukan. Misalnya terdapat dalam ungkapan al-Mutali artinya penyanyi latar dengan suara tinggi, atau $j a^{\prime} a t$ al-khailu tataliyan artinya kuda-kuda itu datang beriringan, atau qad ja'alat dalwa tastatliyani, wa lā urídu tabi'a al-qarin artinya ia menjadikan bintang dalwa mengikutiku, tapi aku tidak ingin mengikuti kekasihku. Pada masa Alquran turun terjadi upaya transendentalisasi (pe-naikkelas-an) (Ismail, n.d.142) kata tilawah. Maknanya menjadi ungkapan (penerangan, penjelasan dan pengajaran) yang mendorong untuk diadopsi menjadi nilai pegangan hidup. Penerangan, penjelasan dan pengajaran dari tilawah sifatnya implikatif dalam kehidupan audiens. Yaitu berupa nilai-nilai maupun prinsip yang hendaknya diimplementasikan dalam tataran praktis dan dijadikan pedoman dalam berkehidupan. Makna yang muncul pada masa ini yaitu menjelaskan dengan rinci dan sesuai dengan realitas, bukan bersifat fantasi, agar dijadikan prinsip hidup; menceritakan kisah kabar atau berita dengan jelas, agar menjadi suri tauladan dalam hidup; menerangkan dengan rinci ketetapan hukum, agar dijadikan nilai moral dalam hidup; menguraikan dengan jelas agar audiens tercerahkan; menerangkan dengan tulus sehingga merasuk ke dalam hati dan membuat audiens tersentuh; mengungkapkan secara logis dan sesuai dengan realitas agar dapat dipercaya; menyampaikan dengan logis; memperdengarkan yang menyentuh hati dan akal; menyampaikan penjelasan dengan kokoh secara argumentatif agar tidak ada celah untuk dibantah; menerangkan dengan jelas agar menjadi peringatan dan pelajaran; mempelajari dan mengamalkan; mengajarkan secara logis dan sesuai realitas. Dari makna-makna tersebut tidak ada satu pun yang merujuk pada pengiringan atau tindakan mengikuti (baik badani atau meneladani) bendawi atau kemakhlukan. Pada masa setelah Alquran, terdapat suatu perlombaan Alquran yaitu MTQ. Tapi spirit maknanya telah mengalami pergeseran. Meskipun dalam tilawah pun melibatkan tindakan membaca dan salah satu maknanya adalah membaca, tetapi apabila dibandingkan dengan makna yang sebenarnya dikehendaki oleh Alquran, maka dapat disimpulkan bahwa makna tilawah pada saat ini mengalami penyempitan makna. 


\section{Singgungan Makna Qiraah dan Tilawah dilihat dari Medan Semantik keduanya}

Dari medan semantik gabungan yang diperoleh dari analisis sintagmatik dan paradigmatik, kata

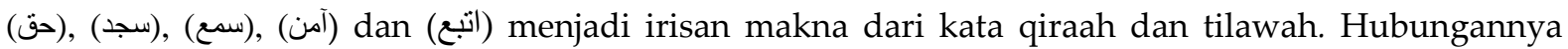
dengan kata (حق)), proses dari keduanya sama-sama bisa mengantarkan pada kebenaran yang bukan bersifat fantasi. Hubungannya dengan (سجد), proses dari keduanya sama-sama bisa mengantarkan pada sikap merendahkan diri di hadapan Sang Pencipta. Hubungannya dengan (استمع), dalam prosesnya keduanya sama-sama diantarkan melalui pendengaran. Hubungannya dengan (آمن)( النع), proses keduanya sama-sama bisa mengantarkan menuju iman. Hubungannya dengan (اتبع), keduanya samasama mengandung wujud yang dapat diikuti. Posisi antara qiraah dan tilawah, dalam tilawah pasti melibatkan qiraah karena subjek tilawah dan audiens tilawah sudah tentu melakukan proses kognisi. Tetapi kepentingan tilawah dan baru disebut tilawah, apabila hasil qiraah dari subjek dan audiens tilawah, menjadikannya sebagai pedoman dan prinsip dalam hidup. Karena secara struktur kalimat, objek tilawah mempunyai kapasitas yang mencukupi untuk kepentingan tersebut. Bukan berarti dalam qiraah tidak mampu melahirkan nilai-nilai yang bisa dijadikan pedoman dan prinsip hidup. Tentu saja bisa dan idealnya memang begitu. Tapi hal yang ditekankan dan menjadi standar kepentingan qiraah hanyalah pelaksanaan proses kognisinya. Sehingga dapat disimpulkan tilawah sudah pasti qiraah. Tetapi qiraah belum tentu tilawah. Bentuk sinonim seperti ini dinamakan sinonim selaras. Sinonim selaras adalah beberapa kata atau ungkapan yang memiliki komponen makna yang sama, tetapi satu di antaranya memiliki komponen makna yang agak luas. (Arifin, 2015, 7)

Meskipun kata qiraah dan tilawah berdasarkan analisis sintagmatik-paradigmatiknya bersinonim, berdasarkan analisis-sintagmatiknya pula kedua kata tersebut menunjukkan perbedaannya, yang bahkan lebih beragam dari irisannya. Medan semantik kata qiraah yang tidak

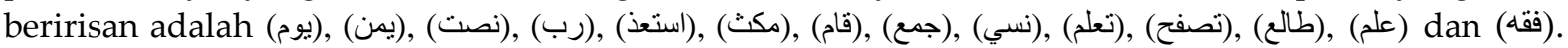

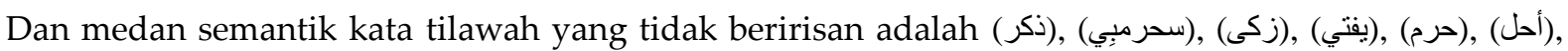

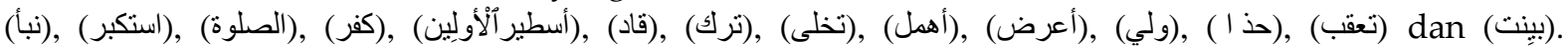
Sehingga pada dasarnya Alquran itu anti sinonimitas, karena dalam pandangan Syahrur, penerimaan terhadap sinonimitas hanya akan mereduksi kandungan makna masing-masing katanya yang kaya akibat kemukjizatan Alquran, terutama dari aspek linguistiknya.

\section{Analisis Makna Qiraah dan Tilawah Perspektif Anti Sinonimitas Syahrur}

Agar maksud penulis bisa sampai, akan didemonstrasikan bagaimana Syahrur, berawal dari ingkar terhadap sinonimitas, melakukan eksplorasi makna dan menghasilkan konsep baru melalui kosakata yang dianggap sinonim sebagai berikut(Syahrur 2018). Banyak orang bertanya, apakah perbedaan antara al-kitäb dan al-qur'ān. Surah Al-Fäthịh mendapat sebutan fätihatul kitäb dan bukan fätihatul qur'ān. Dalam surah Al-Baqarah[2]:2, 53

$$
\text { ذَكِكَ الْْكِتَابُ لَ رَيْبَ فِيهِ هُدَى لِلْمَتَّقِينَ (2) }
$$

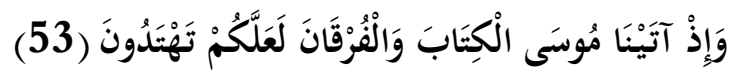

Dalam ayat di atas, al-kitab adalah hudan lilmuttaqin dan al-qur'an adalah hudan linnās. Muttaqin pasti merupakan manusia tapi manusia belum tentu muttaqin. Oleh sebab itu, Allah berfirman alqur'ān adalah hudan linnās dan al-kitab adalah hudan lilmuttaqin. Maka al-kitab wajib mengandung qur'an, karena muttaqin termasuk ke dalam golongan manusia tapi tidak semua manusia termasuk golongan muttaqin. Jadi di dalam al-kitab terkandung juga hal lain yang melengkapi sebagai tambahannya, yaitu al-qur'ān. Orang-orang yang mengikuti al-kitab konsekuensinya menjadi muttaqin. Itulah kenapa Allah memberi kita detil dari al-kitab yang diperuntukkan untuk manusia sekaligus muttaqin yaitu, 


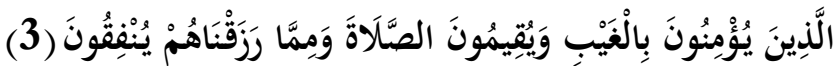

Maksudnya, yu'minūna bil ghaibi (kandungan yang diperuntukkan bagi manusia) adalah alqur'ān dan sisanya yaitu wa yuqimūna al-șalāta wa mimmä razaqnahum yunfiqūn (kandungan yang diperuntukkan bagi muttaqin) adalah bagian dari al-kitab bukan al-qur'ān. Al-qur'ān membahas sesuatu yang lain, yaitu tentang hal-hal gaib (tidak diketahui/tidak disadari) dan perkara gaib merupakan bagian dari nubuwwah. Inilah kenapa Muhammad saw. dinamakan Nabi dan bukan Rasul. Allah berfirman al-qur'ān (yang merangkan perkara gaib), surah $\overline{A l i}$ Imrān ayat 185

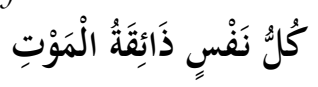

Apakah seseorang menyadarinya atau tidak, menerimanya atau tidak, mati akan menghampiri setiap orang. Jadi dalam al-qur'ān tercantum hudan linnass, karena kandungannya perlu diketahui seluruh manusia. Oleh karena itu, al-qur'an adalah kumpulan perkara gaib yang tidak terlihat dan tidak diketahui (disadari), yang terbagi menjadi dua tipe yang berbeda. Yang pertama hukum alam yang tidak terlihat (ghaibiyyāt al-thabi'ah), yang kedua sejarah yang tidak terlihat (ghaibiyyāt al-tärikh). Hukum alam yang tidak terlihat termasuk di dalamnya penciptaan langit dan bumi, hari kebangkitan, surga, neraka dan penciptaan manusia, semuanya terkandung di dalam al-qur'ān. Oleh karena itu, semua pemberitaan tersebut diperuntukkan bagi semua manusia baik dipercaya atau tidak. Kemudian hal yang kedua, yaitu perkara sejarah (peristiwa) yang tidak terlihat tapi telah diarsipkan (terjadi). Al-qur'an mengandung peristiwa hukum alam yang mana menyangkut percaya atau tidak percaya bukan menyangkut patuh-tidak patuh (taat-tidak taat), di dalamnya juga mengandung peristiwa sejarah dan keduanya menjadi satu yang diberi nama al-hadis $\backslash$ (pemberitaan). Jadi kandungan al-qur'an menyangkut percaya atau tidak percaya (menerima atau mendustakan), bukan tentang patuh-tidak patuh, taat-tidak taat. Sehingga, Kandungan al-qur'ān urusannya terbagi antara kebenaran (haq) dan kesalahan (batil), di dalam hukum alam dan sejarah. Sedangkan risalah urusannya terbagi antara yang diperbolehkan (halal) dan yang dilarang (haram) di dalam tingkah laku sewajarnya manusia. Jadi yang satu terfokus pada peristiwa hukum alam yang meliputi, baik disadari atau tidak dan yang lain terfokus pada hal yang boleh dilakukan atau tidak boleh dilakukan.

Dalam melakukan demonstrasi eksplorasi makna sehingga menghasilkan konsep baru yang berawal dari ingkar terhadap sinonimitas, Syahrur meminjam konsep-konsep metodologis strukturalisme linguistik yang digagas oleh Ferdinand de Saussure, yang juga dipakai Izutsu dalam metode analisis semantik. Hal ini terlihat dari asumsi-asumsi yang beliau adopsi (dimana telah penulis paparkan di poin gagasan anti sinonimitas Syahrur) yang menjadi titik berangkat untuk sampai pada kesimpulan anti sinonimitas, sangat bersinggungan dengan prinsip linguistiknya Ferdinand de Saussure yang nantinya menjadi prinsip suatu aliran bahasa yang dinamakan strukturalisme linguistik. Juga pembangunan hipotesis demi hipotesis mengenai al-kitab, al-qur'an dan al-furqān yang beliau lakukan, yang melibatkan proses sintagmatik-paradigmatik dan pengelompokan ayat. Perbedaan kontrasnya dengan semantik Izutsu adalah Syahrur tidak melibatkan analisis diakronik suatu term. Sehingga, tidak mengantarkannya kepada pandangan dunia term tersebut yang dalam istilah Izutsu disebut weltanschauung. Hal ini dapat dimaklumi mengingat beliau di banyak kesempatan menjelaskan bahwa Alquran seharusnya dibaca dan dipahami bukan melalui produk pemikiran abad klasik, melainkan seolah-olah "Rasulullah baru saja wafat dan memberitahukan kepada kita tentang Kitab tersebut"(Syahrur, n.d.44). Dari pernyataan tersebut, titik tekan Syahrur ada pada upaya kontekstualisasi teks. Maka dari itu, beliau mengerjakan proyek ambisius berupa melakukan pembacaan ulang dengan perangkat ilmu-ilmu abad ke-20. Sehingga standar kebasahan suatu tafsir atau pemahaman bagi Syharur adalah konstekstualisasinya dengan kekinian. Meskipun dapat dikatakan pernyataan tersebut tidak konsisten karena beliau menggunakan $M u^{\prime}$ jam Maqāisisal-lughah-nya Ibnu Faris sebagai pegangan referensi penting oleh beliau dalam menetapkan perbedaan makna lafaz yang dibahas(Syahrur, n.d.24). Memang Ibnu Faris 
pun menyangkal sinonimitas dalam bahasa sehingga Syahrur merasa satu pendapat dengannya, tetapi Ibnu Faris melibatkan syair-syair jahiliyah sebagai bagian dari proses melacak perbedaan makna tersebut. Dan dalam beberapa kasus, Syahrur kerap menggunakan hadis Nabi dalam melakukan pengungkapan makna.

Dari hasil analisis semantik di atas, kata qiraah dan tilawah memang merupakan sinonim. Meskipun begitu pada dasarnya Alquran itu anti sinonimitas, karena masing-masing kata menunjukkan perbedaan yang signifikan (dilihat dari jaringan makna yang dikandungnya). Setelah dilakukan penelitian, penulis sampai pada kesimpulan bahwa teori Syahrur mengenai anti sinonimitas adalah benar. Terbukti dari penelitian yang penulis lakukan, kata qiraah dan tilawah memiliki makna yang berbeda. Kata qiraah titik tekannya, Alquran memberitahukan, tindakan menghimpun atau mengumpulkan bukan merujuk pada keterhimpunan atau keberkumpulan bendawi yang umum. Tetapi merujuk pada proses kognisi manusia, karena itu lebih bermanfaat dan penting untuk diketahui manusia. Kata qiraah merujuk kepada objek yang beragam baik berupa bacaan yang benar atau suci yaitu Alquran, bisa juga tidak demikian (di tempat lain menyebut catatan amal). Atau bahkan di tempat lain tidak disebutkan objeknya sama sekali. Karena, yang menjadi penekanan adalah proses kognisinya (yaitu memahami, menela'ah, melafalkan, mempelajari, menganalisa dan seterusnya) tidak peduli baik objeknya hadir atau tidak, suci atau profan. Sedangkan kata tilawah titik tekannya, Alquran memberikan alternatif juga anjuran bagi manusia mengenai jawaban dari pertanyaan apa yang seharusnya diikuti dan layak diikuti untuk dijadikan sebagai pedoman, pandangan dan prinsip hidup. Yaitu ayat-ayat-Nya yang berwujud verbal maupun non-verbal yang tidak diragukan lagi keagungan, kesucian dan relevansinya dengan realitas. Sehingga, objek dari kata tilawah pasti merupakan hal yang benar dan suci. Berbeda dengan qiraah, tilawah mengharuskan adanya kehadiran objek sebagai rujukan. Karena terdapat kepentingan untuk menjadikannya sumber pedoman hidup.

Telah disinggung bahwa titik tekan Syahrur dalam memahami Alquran ada pada upayanya dalam melakukan kontekstualisasi teks. Dari uraian di atas, pemaparan mengenai kedua kata tersebut masih terlihat abstrak dan sedikit sulit untuk dicerna secara mudah, karena bentuknya berupa konsep. Apabila perlu mengambil suatu bentuk contoh konkret sehingga mudah dipahami, maka qiraah dalam konteks sekarang adalah tindakan menelaah, memahami, menyimak, mengkaji atau melakukan penelitian terhadap suatu hal dan yang sejenisnya. Sedangkan tilawah adalah pengajaran di kelas pada umumnya, pengajian kitab di pesantren, pidato, seminar ilmiah dan yang sejenisnya. Dalam kasus seminar ilmiah misalnya subjek tilawah adalah orang punya kapabilitas tertentu sehingga diberi kesempatan berbicara dan didengarkan, karena telah melakukan kajian ilmiah yang menghasilkan kebenaran empiris, Juga membawa serta hasil penelitiannya tersebut berupa makalah sebagai objek, yaitu rujukan yang akan diseminarkannya. Di dalam seminar ilmiah, semua proses tilawah terjadi. Kedua bentuk tersebut tentu saja hanya merupakan contoh konkret yang akan berubah seiring berubahnya zaman dan waktu. Sebagaimana Syahrur yang memahami yu'minūna bil ghaibi, tidak hanya sebagai syarat keberimanan secara transenden berupa diakuinya keberadaan alam lain setelah mati. Tapi beliau lebih luas memahaminya menjadi segala perkara yang tidak terlihat dan tidak diketahui (disadari), yang terbagi menjadi dua tipe yang berbeda, yaitu hukum alam yang tidak terlihat (ghaibiyyāt al-thabi'ah) (seperti akan dialaminya kematian oleh setiap makhluk yang bernyawa), dan sejarah yang tidak terlihat (ghaibiyyāt al-tärikh). Yang perlu digarisbawahi dari perspektif Syahrur adalah upaya kontekstualisasinya. Karena yang beliau khawatirkan, apabila pemaknaan terhadap Alquran tidak dibawa ke dalam konteks sekarang, akibatnya Alquran akan tidak relevan dengan pengalaman kehidupan riil manusia sehingga yang terjadi adalah Alquran menjadi terasing dari kehidupan manusia itu sendiri. Tentu itu merupakan hal yang buruk, karena pada akhirnya teks Alquran akan ditinggalkan (akibat ketidakrelevanannya). 


\section{Simpulan}

Setelah dilakukan kajian, pemaparan dan penelitian yang penulis lakukan, maka diperoleh beberapa kesimpulan yaitu terkait latar belakang pemikiran anti sinonimitas Muhammad Syahrur dan makna qiraah dan tilawah dalam Alquran perspektif anti sinonimitas Syahrur. Berawal dari asumsi Syahrur mengenai Alquran yang mengandung sisi kemukjizatan ilmiah, sedangkan untuk memahaminya diperlukan metode historis-ilmiah (al-manhaj al-tärikhi al-'ilmi) yang mana menuntut penolakan terhadap fenomena sinonimitas dalam bahasa dan menuntut studi yang mendalam terhadap setiap terma yang selama ini dianggap sinonim. Adapun metode ini diperkenalkan oleh Ja'far Dek al-Bab lewat penelitiannya, yaitu al-Khașaìs al-Binwiyah li al-Arabiyah fi Dau'i al-Dirāsāt alLisāniyah al-Hadișah yang mana beliau ciptakan asasnya berdasarkan perspektif Abu Ali al-Farisi yang berasal dari dua teori yang saling melengkapi, yaitu teorinya Ibnu Jinni dan al-Jurjani. Yang selanjutnya ini mengerucut di dalam teorinya Abu Ali al-Farisi, yaitu berasumsi bahwa; Pertama, bahasa adalah sebuah sistem. Kedua, Bahasa adalah hasil kesepakatan dan hubungan struktur \& fungsi bahasa yang berkaitan dengan praktik bahasa. Ketiga, Keterkaitan bahasa dengan pikiran.

Adapun mengenai pemaknaan kata qiraah dan tilawah, kata qiraah titik tekannya, Alquran memberitahukan, tindakan menghimpun atau mengumpulkan bukan merujuk pada keterhimpunan atau keberkumpulan bendawi yang umum. Tetapi merujuk pada proses kognisi manusia, karena itu lebih bermanfaat dan penting untuk diketahui manusia. Kata qiraah merujuk kepada objek yang beragam baik berupa bacaan yang benar atau suci yaitu Alquran, bisa juga tidak demikian (di tempat lain menyebut catatan amal). Atau bahkan di tempat lain tidak disebutkan objeknya sama sekali. Karena yang menjadi penekanan adalah proses kognisinya (yaitu memahami, menela'ah, melafalkan, mempelajari, menganalisa dan seterusnya) tidak peduli baik objeknya hadir atau tidak, suci atau profan. Sedangkan kata tilawah titik tekannya, Alquran memberikan alternatif juga anjuran bagi manusia mengenai jawaban dari pertanyaan apa yang seharusnya diikuti dan layak diikuti untuk dijadikan sebagai pedoman, pandangan dan prinsip hidup. Yaitu ayat-ayat-Nya yang berwujud verbal maupun non-verbal yang tidak diragukan lagi keagungan, kesucian dan relevansinya dengan realitas. Sehingga objek dari kata tilawah pasti merupakan hal yang benar dan suci. Berbeda dengan qiraah, tilawah mengharuskan adanya kehadiran objek sebagai rujukan. Karena terdapat kepentingan untuk menjadikannya sumber pedoman hidup.

Telah disinggung bahwa titik tekan Syahrur dalam memahami Alquran ada pada upayanya dalam melakukan kontekstualisasi teks. Dari uraian di atas, pemaparan mengenai kedua kata tersebut masih terlihat abstrak dan sedikit sulit untuk dicerna secara mudah, karena bentuknya berupa konsep. Apabila perlu mengambil suatu bentuk contoh konkret sehingga mudah dipahami, maka qiraah dalam konteks sekarang adalah tindakan menelaah, memahami, menyimak, mengkaji atau melakukan penelitian terhadap suatu hal dan yang sejenisnya. Sedangkan tilawah adalah pengajaran di kelas pada umumnya, pengajian kitab di pesantren, pidato, seminar ilmiah dan yang sejenisnya. Dalam kasus seminar ilmiah misalnya subjek tilawah adalah orang punya kapabilitas tertentu sehingga diberi kesempatan berbicara dan didengarkan, karena telah melakukan kajian ilmiah yang menghasilkan kebenaran empiris Juga membawa serta hasil penelitiannya tersebut berupa makalah sebagai objek, yaitu rujukan yang akan diseminarkannya. Di dalam seminar ilmiah, semua proses tilawah terjadi. Kedua bentuk tersebut tentu saja hanya merupakan contoh konkret yang akan berubah seiring berubahnya zaman dan waktu. Sebagaimana Syahrur yang memahami yu'minūna bil ghaibi, tidak hanya sebagai syarat keberimanan secara transenden berupa diakuinya keberadaan alam lain setelah mati. Tapi beliau lebih luas memahaminya menjadi segala perkara yang tidak terlihat dan tidak diketahui (disadari), yang terbagi menjadi dua tipe yang berbeda, yaitu hukum alam yang tidak terlihat (ghaibiyyāt al-thabi'ah) (seperti akan dialaminya kematian oleh setiap makhluk yang bernyawa), dan sejarah yang tidak terlihat (ghaibiyyāt al-tärikh) (seperti ). Yang perlu digarisbawahi dari perspektif Syahrur adalah upaya kontekstualisasinya. Karena yang beliau khawatirkan, apabila pemaknaan terhadap Alquran tidak dibawa ke dalam konteks sekarang, 
akibatnya Alquran akan tidak relevan dengan pengalaman kehidupan riil manusia sehingga yang terjadi adalah Alquran menjadi terasing dari kehidupan manusia itu sendiri. Tentu itu merupakan hal yang buruk, karena pada akhirnya teks Alquran akan ditinggalkan (akibat ketidakrelevanannya).

\section{Referensi}

Al-Sabt, Khalid bin Usman. 1421. Qawa’id Al-Tafsìr Jam'an Wa Dirāsatan. Madinah: Dar al-Affan. - - - Q Qawä'id Al-Tafsir Jam'an Wa Dirāsatan. Madinah: Dar al-Affan.

Arifin, E. Zaenal. 2015. “'Kesinoniman Dalam Bahasa Indonesia',." Pujangga: Jurnal Bahasa dan Sastra 1(1): 7.

Baqi, Muhammad Fuad Abdul. Al-Mu'jam Al-Mufahras Li Alfäz $\backslash$ Al-Qur'ān Al-Karim. Indonesia: Maktabah Dahlan.

Dindin Moh Saepudin, M.Solahudin dan Izzah Faizah.Siti Rusydati Khairani. "Iman Dan Amal Saleh Dalam Alquran (Studi Kajian Semantik)." Al-Bayan: Jurnal Studi Al-Qur"an dan Tafsir 2(1).

Harb, Ali. 2003. Kritik Nalar Al-Quran, Trans. M. Faisol Fatawi. Yogyakarta: LKiS.

Hidayat, Arifin. 2017. “'Metode Penafsiran Alquran Menggunakan Pendekatan Linguistik: Telaah Pemikiran M. Syahrur',." Jurnal Madaniyah 7(2): 207.

Hikmat Ullah Khan, Syed Muhammad Saqlain, Muhammad Shoaib, and Muhammad Sher. 2019. "Ontology Based Semantic Search in Holy Quran Hikmat Ullah Khan, Syed Muhammad Saqlain, Muhammad Shoaib, and Muhammad Sher." International Journal of Future Computer and Communication 2(6).

Ismail, Ecep. 2016a. "'Analisis Semantik Pada Kata Ahzābdan Derivasinya Dalam Alquran',," Al-Bayan: Jurnal Studi Alquran dan Tafsir 1(2): 142.

- - - 2016b. "Analisis Semantik Pada Kata Ahzāb Dan Derivasinya Dalam Al-Quran." Al-Bayan: Jurnal Studi Al-Qur'an dan Tafsir 1(2).

Izutsu, Toshihiko. 2003. Relasi Tuhan Dan Manusia Pendekatan Semantik Terhadap Alquran, Trans. Aguslim Fahri Husein Dkk. Yogyakarta: Tiara Wacana.

Malik, Abdul. 2017. “'Tafsir Alqur'an Paradigma Integratif: Studi Atas Qiraah Althaniyah Muhammad Syahrur",." Jurnal Pemikiran Islam dan Filsafat Al-A'raf XIV(1): 120.

Mubarok, Ahmad Zaki. 2007. Pendekatan Strukturalisme Linguistik Dalam Tafsir Alqur'an Kontemporer Ala Syahrur. Yogyakarta: eLSAQ Press.

Riyanto, Waryani Fajar. 2014. “Antisinonimitas Tafsir Sufi Kontemporer.” Episteme 9(1).

Rofiq Nurhadi. 2017. "Pro Kontra Sinonimi Dalam Al-Qur'an." Jurnal Al Bayan 9(2).

Shihab, M. Quraish. 2015a. Kaidah Tafsir. Tangerang: Lentera Hati.

- - - 2015b. Kaidah Tafsir. Tangerang: Lentera Hati.

Syahrur. Al-Kitab Wa Al-Qur'an: Qira>'ah Mu'a>słirah.

-- -. Al-Kitab Wa Al-Qur'ān: Qiraah Mu'äsirah,.

- - - Al-Kitab Wa Al-Qur'ān: Qiraah Mu'asirah.

Syahrur, Muhammad. 1994. Dirāsāt Al-Islämiyāt Al-Mu'așîrah Fi Al-Daulah Wa Al-Mujtama'. Damaskus: al-Ahali li al-Tiba'ah wa al-Nasyr wa al-Tauzi'.

- - - 2015. Al-Kitab Wa Al-Qur'än: Qira>'ah Mu'a>s\}irah,Trans. M. Firdaus. Bandung: Marja.

- - - 2018. “'The Book and The Quran - Dr.Mohamad Shahrour (Episode.1),."”

T.Izutsu. 1997. Relasi Tuhan Dan Manusia Pendekatan Semantik Terhadap Al-Qur'an. Yogyakarta: Tiara Wacana Yogya.

Yunus, Mahmud. 1972. Arab Indonesia. Jakarta: Mahmud Yunus Wa Dzuriyyah.

Yusuf, Muhammad. 2014. "Bacaan Kontemporer: Hermeneutika Alquran Muhammad Syahrur',." Jurnal Diskursus Islam 2(1): 55.

Zenrif, M. F. 2008. Sintesis Paradigma Studi Alquran. Malang: UIN Malang Press.

Zulfikar, Eko. 2018. "Makna UUlū Al-Albāb Dalam Al-Qur'an: Analisis Semantik Toshihiko Izutsu." Jurnal Theologia 29(1).

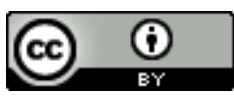

(0) 2020 by the authors. Submitted for possible open access publication under the terms and conditions of the Attribution 4.0 International (CC BY 4.0) license (https://creativecommons.org/licenses/by/4.0/). 